Research Articles

\title{
Features of Microelement Composition of Ordinary Chernozems of the Azov and Lower Don Regions
}

\author{
${ }^{1}$ Tatiana M. Minkina, ${ }^{2}$ Nikolay N. Miroshnichenko, ${ }^{2}$ Aleksandr I. Fateev, ${ }^{3}$ Galina V. Motuzova, \\ ${ }^{1}$ Saglara S. Mandzhieva, ${ }^{1}$ Svetlana N. Sushkova and ${ }^{1}$ Olga A. Biryukova \\ ${ }^{I}$ Southern Federal University, Rostov-on-Don, 344090, prosp. Stachki, 194/1, Russia \\ ${ }^{2}$ Sokolovskii Institute of Soil Science and Agrochemistry, \\ Ukrainian Academy of Agrarian Sciences, ul. Chaikovskogo 4, Kharkiv, 61024 Ukraine \\ ${ }^{3}$ Lomonosov Moscow State University, Soil Science Faculty, Moscow, 119991, Vorobjevy Gory, Russia
}

Article history

Received: 24-02-2015

Revised: 4-03-2015

Accepted: $10-7-2015$

Corresponding Author:

Saglara Sergeevna Mandzhieva

Southern Federal University,

Rostov-on-Don, 344090, prosp.

Stachki, 194/1, Russia

Email: msaglara@mail.ru

\begin{abstract}
Ordinary chernozems in the Azov Plain have a low background content of mobile zinc compounds, a sufficient supply with copper and an increased content of lead compounds. This specificity of the regional microelement composition is due to the high carbonate content in the soil profiles, the natural enrichment of littoral geochemical landscapes and the effect of the significant sources of microelement emission (Mariupol metallurgical enterprises, Novocherkassk regional power station, etc.). The high buffer capacity of soils in the Azov region significantly mitigates the negative effects of pollution.
\end{abstract}

Keywords: Background Content, Chernozems, Emission, Microelements, Pollution

\section{Introduction}

Soil is the main source of trace elements for plants both as micronutrients and pollutants. The origin of trace elements influences their behavior in soils and therefore controls to some extent their bioavailability. The distribution and speciation of the trace elements of anthropogenic origin are affected as a result of various pedogenic processes, among which the fixation by clay minerals and binding/complexing by Soil Organic Matter (SOM) play a crucial role (Kabata-Pendias, 2004).

The microelement composition of ordinary chernozems was developed under the nonpercolative water conditions with weakened leaching and enhanced biogenic accumulation. This was favored by the shallow occurrence of carbonates (near the surface or within the upper humus horizon) in the soil profile, which decreases the supply of the soil with mobile microelements. The distribution of elements in the ordinary chernozem is related to the homogeneous particle size distribution in its profile; therefore, the total microelement composition relatively little changes and the accumulation maximums are confined to the humus-accumulative and calcareous horizons (Satrio et al., 2009; Alshaebi et al., 2009).

The soil-climatic conditions in the Azov-Low Don region favor the development of vegeculture, horticulture and viticulture (Minkina et al., 2010) and the near coastal markets ensure the increased economic attractiveness of these agrarian branches. However, the saturation of the region with industrial objects significantly affected the microelement composition of the soil and plant cover and created ecological and toxicological risks (Heryati et al., 2011; Minkina et al., 2012). There are a large number of sites worldwide polluted with trace elements as a result of human activities. By the volume of industrial emissions, Mariupol (Ukrain) (330380 thousand t) and Novocherkassk (Russia) (90-110 thousand $\mathrm{t}$ ) are among the most significant pollution sources not only for the Azov region, but also for the entire Ukraine and Russia.

The degree of soil contamination is determined by the distance from the sources of pollutant emissions, the prevailing wind diagram and the soils properties including such as organic matter, oxides as well as soil structure and profile development (Kabata-Pendias, 2004; Mehes-Smith et al., 2013; Minkina et al., 2012; 2013). Due to the high adsorption capacity and weakly alkaline reaction, the chernozems of the Azov and Low Don regions are characterized by the increased resistance to technogenic pollution and are capable to retain significant amounts of microelements (Satrio et al., 2009).

The aim of the work was to determine the contents of anthropogenically caused microelements in the 
chernozems of the Azov and Low Don regions for the objective assessment of the pollution areas and the prediction of their potential expansion.

\section{Materials and Methods}

The studies covered the affected zones near the Novocherkassk Power Station (NPS) in Rostov region (Russia), "Azovstal" metallurgical enterprises and "Markokhim" coking enterprises (Mariupol, Ukrain) and "Azovkabel" power cable manufacturer, "AZMOL" lubricant manufacturer (Berdyansk, Ukrain) (Fig. 1).

The objects of study were Ordinary or Calcic Chernozems, ID 14-2 (FAO, 1988), prevail in the soil cover of the sloping Azov Plain spread from the Donetsk Range to the Azov Sea and the lower course of the Don River. The parent rocks of these soils predominantly consist of carbonate loess-like clays and loams, 6 to $50 \mathrm{~m}$ thick, of glaciofluvial, alluvial and alluvial-deluvial origin containing 4 to $17 \% \mathrm{CaCO}_{3}$. These soils have silty clay loamy and sandy clay textures (50-66\% physical clay, $28-41 \%$ clay). The content of humus in the upper horizon is $3.8-4.7 \%$; the actual acidity varies from $\mathrm{pH} 7.2$ to $\mathrm{pH}$ 8.0. They were also characterized by low a Cation Exchange Capacity (CEC), namely, $10 \mathrm{mmol}(+) / 100 \mathrm{~g}$ soil.

To obtain representative data, soil samples were taken from the test plots no less than $2500 \mathrm{~m}^{2}$ in area in accordance with the prevailing wind direction. Areas with similar topographies and soil covers not subjected to agrotechnical operations during the past $10-15$ years were selected as sampling sites. All sampling sites were located no closer than $100 \mathrm{~m}$ to buildings and roads. A composite sample of $600 \mathrm{~g}$ was formed from three $200 \mathrm{~g}$ point samples taken from each soil horizon. The procedures of sampling and sample preparation to analysis were performed according to the standards methods (GOST 17.4.3.01-83; GOST 17.4.4.02-84).

The mobile compounds of HM were analyzed by using the $1 \mathrm{~N}$ ammonium acetate buffer $\left(\mathrm{NH}_{4} \mathrm{Ac}\right) \mathrm{pH} 4.8$ (soil: solution ratio 1: 10, extraction time $18 \mathrm{~h}$ ) (Minkina et al., 2008). Their concentrations in the extracts were determined with Atomic Absorption Spectrophotometry (AAS). The allowed deviation AAS methods for elements determination in soil is not more than $10-15 \%$. Analytical quality of measurements was controlled by analyzing reference standard soil sample "Chernozem" № 29107. Duplicates and reagent blanks were also used as a part of the quality control.

The results of chemical analysis correspond to the mean of three replicates. Descriptive data analysis, comprising minimum value, mean value, maximum value and standard deviation, was carried out with EXCEL 2010. Data mean were calculated using Microsoft EXCEL. Statistical significance of the differences among means was determined by Fisher LSD test. Differences were considered not significant at values of $\mathrm{p}>0.05$.

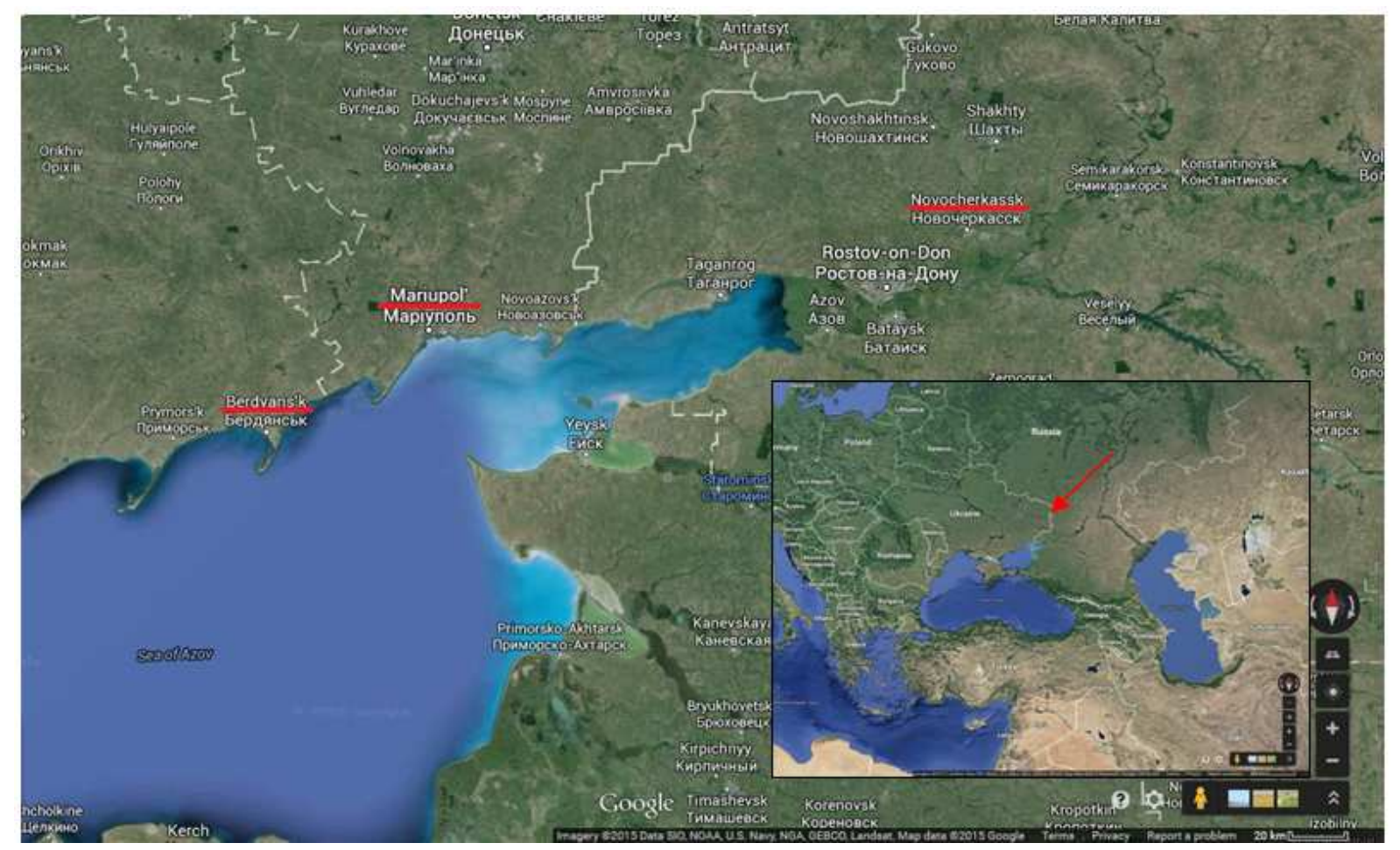

Fig. 1. Map of the Azov and Low Don regions showing areas of sampling 


\section{Results}

Mobile microelements concentrations in soil and horizons near Mariupol and Berdyansk (Ukrain) are summarized in Table 1 and Fig. 2.

The urban background of mobile microelements in Mariupol was two-three-fold above the background of most typical soils. The urbanized background in Berdyansk was lower than in Mariupol for the mobile forms of most microelements and slightly higher for $\mathrm{Zn}$ and $\mathrm{Pb}$. However, the high concentration coefficients of $\mathrm{Zn}$ are related to its low natural content in soils, such that even the six-fold excess can be considered as physiologically favorable and not hazardous.
The direct effect of the NPS is traced to a distance of $25 \mathrm{~km}$ along the wind rose and the smoke plume is clearly traced to the city of Khar'kov (Ukrain). The bulk of pollutants settle within $5 \mathrm{~km}$ from the pollution source along the general direction. A gradual decrease in the content of microelements was then observed, down to the near-background level on the most remote areas.

In the polluted soils, the portion of the metal mobile form increases appreciably. In the soils of the plots located at short distances from the NPS, the portions of mobile $\mathrm{Cu}, \mathrm{Pb}$ and $\mathrm{Zn}$ compounds increase by $2.7,2.5$ and 3.8 times, respectively (Table 2). The occurring changes are mainly directed toward an increase in the portion of more mobile metal compounds with increasing the long-term accumulation of metals.

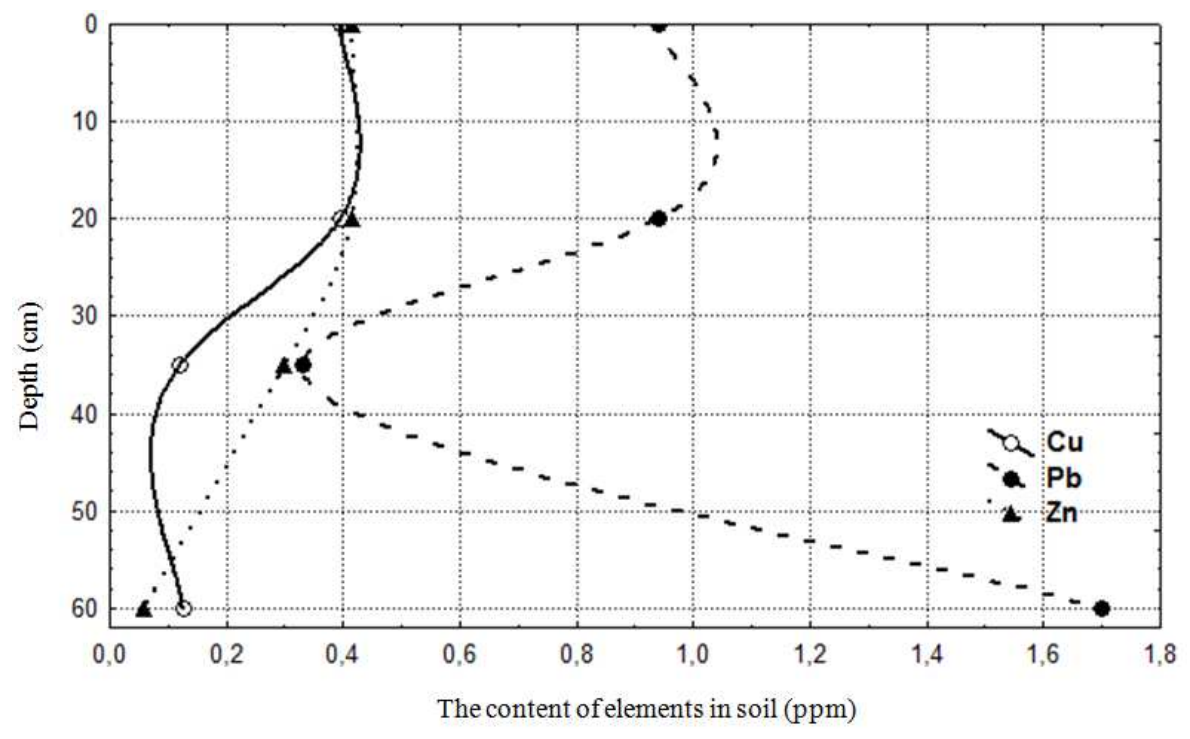

Fig. 2. Distribution of mobile $\mathrm{Zn}, \mathrm{Cu}$ and $\mathrm{Pb}$ forms in the profile of ordinary chernozem (Berdyansk region)

Table 1. Background contents of mobile microelements in the suburban zone, ppm

\begin{tabular}{lllllllll}
\hline Statistical parameters & $\mathrm{Zn}$ & $\mathrm{Cd}$ & $\mathrm{Ni}$ & $\mathrm{Co}$ & $\mathrm{Fe}$ & $\mathrm{Mn}$ & $\mathrm{Pb}$ & $\mathrm{Cu}$ \\
\hline Mariupol & & & & & & & & \\
Minimum & 0.55 & 0.15 & 1.55 & 0.90 & 1.50 & 3.70 & 1.25 & 0.30 \\
Maximum & 1.25 & 0.25 & 2.30 & 1.70 & 3.00 & 18.0 & 3.12 & 0.48 \\
Mean & 0.83 & 0.19 & 1.88 & 1.33 & 2.39 & 8.72 & 2.11 & 0.38 \\
Standard deviation & 0.07 & 0.01 & 0.08 & 0.08 & 0.13 & 1.37 & 0.23 & 0.02 \\
Berdyansk & & & & & & & & \\
Minimum & 0.45 & 0.08 & 0.25 & 0.35 & 2.00 & 6.75 & 0.25 & 0.25 \\
Maximum & 1.58 & 0.25 & 2.30 & 2.15 & 4.00 & 23.0 & 3.88 & 0.95 \\
Mean & 0.80 & 0.19 & 1.08 & 1.40 & 2.66 & 12.6 & 1.62 & 0.51 \\
Standard deviation & 0.11 & 0.02 & 0.19 & 0.20 & 0.18 & 1.87 & 0.47 & 0.07 \\
\hline
\end{tabular}

Table 2. Contents of the metal mobile forms in the soil at different distances from the Novocherkassk power station (North-Western direction), ppm

\begin{tabular}{lccc}
\hline Distance from the NPS $(\mathrm{km})$ & $\mathrm{Zn}$ & $\mathrm{Cu}$ & $\mathrm{Pb}$ \\
\hline 1.2 & 25.0 & 3.5 & 6.4 \\
1.6 & 16.5 & 4.7 & 6.7 \\
2.0 & 13.0 & 4.0 & 4.7 \\
5.0 & 14.0 & 3.2 & 3.0 \\
15.0 & 2.1 & 1.0 & 1.0 \\
20.0 & 1.4 & 0.7 & 3.1 \\
LSD $_{0.05}$ & 2.7 & 0.2 & 0.7 \\
MPC (TsINAO, 1992) & 23.0 & 3.0 & 6.0 \\
\hline
\end{tabular}




\section{Discussion}

Because of the natural and agrogenic variability of microelements in the soils, their pollution is usually identified at shorter distances and significantly depends on the height of emission tubes, especially for $\mathrm{Pb}$. A regional feature of ordinary chernozems is the high content of microelements due to the enrichment of the parent rocks and the low mobility the elements restricted by the presence of carbonates in the soils. This is primarily true for such an essential microelement as $\mathrm{Zn}$. The content of exchangeable and mobile $\mathrm{Zn}$ compounds in the plow layer of chernozems is of $0.1-0.6 \mathrm{mg} \mathrm{kg}^{-1}$ (in gardens and vineyards, to $1-2 \mathrm{mg} \mathrm{kg}^{-1}$ ) and does not change significantly with time (Minkina et al., 2010; Fateev and Pashchenko, 2003; AL-Rajhi, 2014).

The background content of $\mathrm{Cu}$ in the regional soils of different geochemical landscapes varies from 21 to 60 $\mathrm{mg} \mathrm{kg}^{-1}$. This content of the metal is within the normal regulation of plant and animal functions (Fateev and Pashchenko, 2003; Minkina et al., 2013). These values are close to the background content of $\mathrm{Cu}$ in chernozems, which varies from 21 to $30 \mathrm{mg} \mathrm{kg}^{-1}$ (according to different data) and its clarke value for soils $\left(20 \mathrm{mg} \mathrm{kg}^{-1}\right)$ but exceed the regional estimates for the element content obtained more than 37-45 years ago (Minkina et al., 2012). The content of the $\mathrm{Cu}$ mobile form does not exceed $2 \%$ of its total content (Table 1). Under the vineyards, the content of the mobile metal in the soils abruptly increases to $13 \mathrm{mg} \mathrm{kg}^{-1}$, which is due to the application of copper-containing fungicides. A clear tendency of increasing the copper content in the upper humus-accumulative horizon is observed throughout the soil profile, which is related to the close affinity of this biophilic element to soil organic matter (Fig. 1).

The content of lead in ordinary chernozems of the studied region varies within the range from 8 to $78 \mathrm{mg}$ $\mathrm{kg}^{-1}$, the mean value being $21-22 \mathrm{mg} \mathrm{kg}^{-1}$, which exceeds the clarke value $\left(10 \mathrm{mg} \mathrm{kg}{ }^{-1}\right)$ and the background content of the element $\left(12 \mathrm{mg} \mathrm{kg}^{-1}\right)$ for the chernozems of the former USSR. The observed excess lead content in the recent soils can be due to the anthropogenic factors: the variation range of lead content in chernozems was $3.7-23.7 \mathrm{mg} \mathrm{kg}^{-1}$ in 1957 (Minkina et al., 2010). However, this also can be a regional feature related to the natural enrichment of coastal landscapes, because even at a significant distance (more than $20 \mathrm{~km}$ ) from the pollution sources in Berdyansk and Mariupol (Ukrain), the total content of lead was $30-40 \mathrm{mg} \mathrm{kg}^{-1}$ soil and that of its mobile forms reached 3-4 mg kg-1 soil (Table 1). The percentage of exchangeable lead in the background chernozems is $1.4-5 \%$ of its total content, which significantly exceeds the relative contents of exchangeable $\mathrm{Cu}$ and $\mathrm{Zn}$ forms $(<1 \%)$. The size of the $\mathrm{Pb}^{2+}$ ion is closest to that of the $\mathrm{Ca}^{2+}$ ion (the ionic radiuses are 1.3-1.2 for $\mathrm{Pb}^{2+}$ and 1.2-1.1 for $\mathrm{Ca}^{2+}$ ); therefore, their contents in the exchangeable form exceed those of the other metals under study. The local abrupt increases in the contents of mobile lead forms are noted within rice-growing farms in the close vicinity of highways and industrial objects.

\section{Conclusion}

Ordinary chernozems in the Azov Plain and the Low Don region have the low background contents of mobile zinc compounds, the sufficient supply of copper and the increased content of lead compounds. This regional specificity of microelement composition is related to the high carbonate content in the soil profile, the natural enrichment of the coastal geochemical landscapes and the technogenic emission of microelements.

The common urbanized background was established due to the accumulation of biophilic elements was revealed. Our studies revealed a clear confinement of soil cover pollution to the industrial areas of the above-mentioned enterprises and the overlapping of the technogenic dispersion areas from different emission sources.

The effect of the most important sources of pollutions (Mariupol metallurgical enterprises, Novocherkassk regional power station) on the microelement composition of the soil was clearly traced to distances of $20-25 \mathrm{~km}$. Two-three-fold excess over the background level is typical for the $5 \mathrm{~km}$ zone around the emission sources.

\section{Acknowledgment}

This work was supported by the Ministry of Education and Science of the Russian Federation (project no. 5.885.2014/K). Analytical work was carried out on the equipment of Centers for collective use of Southern Federal University "High Technology", grant RFMEFI59414X0002.

\section{Funding Information}

The funders of this manuscript were the Ministry of Science of the Russian Federation.

\section{Author's Contributions}

Tatiana M. Minkina: The head of the investigation, studying of the microelements behavior in soil around the Novocherkassk power station (Russia).

Nikolay N. Miroshnichenko: The head of the investigation, studying of the microelements behavior in soil near the Mariupol and Berdyansk (Ukrain).

Aleksandr I. Fateev: The studying of the microelements behavior in soil (Ukrain).

Galina V. Motuzova: The studying of the microelements behavior in soil (Russia). 
Saglara S. Mandzhieva: Studying of the microelements mobile compounds behavior in soil around the Novocherkassk power station.

Svetlana N. Sushkova: Investigation the buffer capacity of the soil in relation to microelements.

Olga A. Biryukova: Studying of the microelements behavior in soil (Russia).

\section{Ethics}

There are no ethical issues that may arise after the publication of this manuscript.

\section{References}

AL-Rajhi, M.A., 2014. Study of some heavy metals and trace elements. Phys. Int., 5: 128-131. DOI: $10.3844 /$ pisp.2014.128.13

Alshaebi, F.Y., W.Z.W. Yaacob, A.R. Samsudin and E. Alsabahi, 2009. Arsenic adsorption on bauxite mineral using batch equilibrium test. Am. J. Applied Sci., 6: 1826-1830.

DOI: $10.3844 /$ ajassp.2009.1826.1830

FAO, 1988. Yearbook of forest products. Food and Agriculture Organization of the United Nations, Rome.

Fateev, A.I. and Y.V. Pashchenko, 2003. Background contents of microelements in Ukrainian soils. KP Drukarnya, Kharkiv, Ukrainian.

Heryati, Y., A. Abdu, M.N. Mahat, H. Abdul-Hamid and S. Jusop et al., 2011. Comparing the fertility of soils under khaya ivorensis plantation and regenerated degraded secondary forests. Am. J. Applied Sci., 8: 472-480.

Kabata-Pendias, A., 2004. Soil-plant transfer of trace elements-an environmental issue. Geoderma, 122: 143-149. DOI: 10.1016/j.geoderma.2004.01.004
Mehes-Smith, M., K.K. Nkongolo, R. Narendrula and E. Cholewa, 2013. Mobility of heavy metals in plants and soil: A case study from a mining region in Canada. Am. J. Environ. Sci., 9: 483-493. DOI: 10.3844/ajessp.2013.483.493

Minkina, T.M., G.V. Motusova, O.G. Nazarenko and S.S. Mandzhieva, 2010. Heavy Metal Compounds in Soil: Transformation upon Soil Pollution and Ecological Significance. 1st Edn., Nova Science Publishers, Inc., New York, ISBN-10: 1608764664, pp: 184.

Minkina, T.M., G.V. Motusova, S.S. Mandzhieva and O.G. Nazarenko, 2012. Ecological resistance of the soil-plant system to contamination by heavy metals. J. Geochemical Exploration, 123: 33-40. DOI: 10.1016/j.gexplo.2012.08.021

Minkina, T.M., G.V. Motuzova, O.G. Nazarenko, V.S. Kryshchenko and S.S. Mandzhieva, 2008. Forms of heavy metal compounds in soils of the steppe zone. Eurasian Soil Sci., 41: 708-716. DOI: $10.1134 / \mathrm{S} 1064229308070053$

Minkina, T.M., G.V. Motuzova, S.S. Mandzhieva, O.G. Nazarenko and M.V. Burachevskaya et al., 2013. Fractional and group composition of the $\mathrm{Mn}, \mathrm{Cr}, \mathrm{Ni}$, and $\mathrm{Cd}$ compounds in the soils of technogenic landscapes in the impact zone of the Novocherkassk power station. Eurasian Soil Sci., 46: 375-385. DOI: $10.1134 / \mathrm{S} 1064229313040108$

Satrio, A.E., S. Gandaseca, O. Haruna Ahmed and N.M.A. Majid, 2009. Effect of skidding operations on soil carbon storage of a tropical peat swamp forest. Am. J. Environ. Sci., 5: 722-726. DOI: 10.3844 /ajessp.2009.722.726

TsINAO, 1992. Methodological guidelines on determination of heavy metals in Agricultural Soils and Crop Produce. Moscow, Russian. 